\title{
A DIVINDADE COMO PERSONAGEM: NARRATIVAS TESTEMUNHAIS EM SANTUÁRIOS CATÓLICOS (2012-2013)
}

The deity as character: testimonial narratives in catholic shrines (2012-2013)

Jael dos Santos ${ }^{1}$

\section{REAUMO}

A partir de fontes orais produzidas em momentos de ritualização religiosa, o presente texto tem por finalidade refletir sobre algumas estratégias narrativas tendo em conta a noção de "testemunho". No caso, serão problematizadas entrevistas curtas que foram gravadas nos anos de 2012 e 2013 em santuários católicos existentes na região Sudoeste do Paraná. Tendo em vista que foram proferidas para verbalizar os pormenores do "pagamento de promessas" e o exercício do fervor religioso, será pensado o modo como tais falas mobilizam um campo semântico socialmente constituído que posiciona a divindade junto aos fluxos próprios da vida cotidiana.

Palavras-chave: história oral; religiosidade; testemunho;

\begin{abstract}
Thinking about oral sources produced in moments of religious ritualization, this text aims to consider about some narrative strategies considering the concept of "testimony". In this respect, short interviews that were recorded in 2012 and 2013 in Catholic shrines in the Southwest region of Paraná will be discussed. Given that they were uttered to verbalize the details of the "payment of promises" and the exercise of religious fervor, the way such speeches mobilize a socially constituted semantic field which positions the divinity along with the everyday life proper flows will be pondered.
\end{abstract}

Keywords: Oral history; religiosity; testimony;

\section{PRIMEIRAS PALAVRAS:}

O mundo tá perdido, mas com Deus a agente recupera.

(Entrevista com R., M. 2012)

As reflexões que balizaram a escrita desse artigo derivaram da reanálise de um conjunto de entrevistas curtas ${ }^{2}$. Estas foram produzidas em espaços de devoção entre os dias 11 e 12 de

\footnotetext{
${ }^{1}$ Doutor em História pela Universidade Estadual do Oeste do Paraná, Campus de Marechal Cândido Rondon. Professor colaborador no Centro de Ciências Humanas e da Educação da Universidade Estadual do Paraná UNESPAR - Campus de Campo Mourão. E-mail: jaelsantos89@yahoo.com.br.

2 Dois esclarecimentos: a) nesse texto, optou-se por usar a inicial dos nomes dos entrevistados; b) durante a feitura da dissertação, a duração das entrevistas se deu com vistas a perceber o fervor religioso em momentos devocionais. REVISTA RELEGENS THRÉSKEIA - 2021 - UFPR
} 
outubro dos anos de 2012 e $2013^{3}$ e serviram para instrumentalizar uma pesquisa de mestrado ${ }^{4}$. O objeto daquele estudo foi a trajetória sócio-histórica do catolicismo na região Sudoeste do Paraná, tanto do ponto de vista institucional quanto do que se constituiu nos liames da oficialidade.

Nesse ínterim, dentre outros objetivos, foram analisados alguns momentos de elaboração ritual e como tais expressões mantinham nexos com o passado da região. Em face desses objetivos, os lugares de devoção foram buscados por, em tese, conjugarem as linhas gerais do catolicismo existente - tanto os elementos historicamente controlados pela oficialidade quanto as possibilidades abertas aos fiéis para ressignificarem o espaço e as suas próprias práticas religiosas no decorrer do tempo (SANTOS, 2013).

É preciso pontuar que o Sudoeste do Paraná se trata de uma região de reocupação recente, processo que foi iniciado na década de 1940 por estímulos governamentais, tanto em nível estadual quanto nacional. Nesse momento houve o estímulo à migração de indivíduos de "ascendência europeia" advindos de regiões mais a sul, sobretudo do estado do Rio Grande do Sul. Tal perfil populacional era muito bem-quisto pelo estado, inclusive pelos membros da Igreja, por supostamente contar com inclinações ao "valor do trabalho" sistemático, por teoricamente serem capazes de ocupar economicamente as fronteiras agrícolas e por cultivarem práticas religiosas atreladas ao universo da capela e dos sacramentos oficiais, algo que as populações anteriores, de origem luso-brasileira, eram acusadas de não manter com rigor.

Nesse texto, será tematizada uma dessas possibilidades de construção de sentidos, sobretudo a mobilizada em termos mnemônico-narrativos. Desde os primeiros contatos com os lugares de devoção, ambos de devoção mariana, alguns aspectos chamaram a atenção. Entre esses, as estratégias narrativas mobilizadas pelos fiéis para posicionar a divindade junto à cotidianidade, tanto às próprias quanto as do mundo como um todo - algo muito bem sintetizado

\footnotetext{
3 As datas foram escolhidas em função do dia 12 de outubro ser feriado do Dia Nacional de Nossa Senhora Aparecida, instituído pela Lei 6.802/80, ocasião que mobiliza milhões de fiéis católicos a deslocarem-se para espaços de peregrinação.

4 No trabalho de mestrado houve idas a campo em vários espaços de devoção, notadamente grutas interioranas. Nesse texto, porém, serão abordadas fontes produzidas apenas no Santuário de Nossa Senhora Aparecida, localizado no município de Santa Izabel D’Oeste. Sendo suscinto sobre a origem do espaço, e respeitando as narrativas oficiais, o santuário começou como uma gruta na qual houve o depósito de uma imagem de Nossa Senhora Aparecida. O "ato fundacional" se deu pelo pagamento de uma promessa de cura, acontecimento datado do ano de 1975. Como parte da promessa, foi trazida uma imagem diretamente do Santuário Nacional de Aparecida a qual foi posicionada em uma pequena extensão de terra nas proximidades da cidade. Devido à tradição mariana existente na região, principalmente entre as mulheres, tão logo muitas pessoas começaram a ser atraídas para peregrinações e orações de terços. Os dados da paróquia local relevam um aumento exponencial do fluxo para o lugar desde o início da década de 1980. Atualmente, ocorre um evento nominado Romaria Penitencial à Nossa Senhora Aparecida, em todo dia 12 de outubro, evento que reúne cerca de 50 mil pessoas no dia da romaria, além de um intenso fluxo de fiéis durante o ano (SANTOS, 2013, p. 178-187).
} 
na fala de Dona Maria Rodrigues na epígrafe. Dito de outra forma, como Deus, Cristo, as virgens e os santos influenciariam no âmbito temporal e agiriam entremeio aos desígnios e infortúnios próprios do viver humano. Uma das experiências proporcionadas por essa pesquisa foi particularmente emblemática, pois acabou por oferecer uma das categorias que nortearão a feitura desse texto.

Em uma das primeiras visitas ao Santuário Diocesano de Santa Izabel D’Oeste, em 11 de outubro de 2012, abordou-se um senhor que, ao ser questionado sobre a possibilidade de conceder uma pequena entrevista, afirmou: "aqui não se dá entrevista, se dá testemunho". Observando-se retrospectivamente, a assertiva voltou a chamar a atenção, mais precisamente por duas razões: um primeiro elemento diz respeito ao sentido sacralizante dado à abordagem uma vez que não haveria apenas um ato explanatório em curso; um segundo, por sua vez, demarca o lugar de religiosidade como um espaço no qual imperaria tanto a emoção do "aqui", quanto o cálculo racional necessário à sistematização da fala. Nesses termos, o "testemunho" seria, ao mesmo tempo, descrição de um fato e confirmação de um ato: “a divindade está aqui!". Partamos daí.

\section{$O$ ato testemunhal}

A escolha do senhor pelo termo "testemunho" como ideal para definir a "narrativa religiosa" que se seguiria não foi aleatória. O cristianismo tem nessa categoria uma das bases do seu exercício religioso, algo que será pensado nas próximas páginas. Antes, porém, convém levantar alguns pontos sobre a noção de testemunho. Desde meados da metade do século XX, tal gênero vem sendo central em várias obras de caráter histórico e filosófico, algo que reflete as tentativas de se pensar os inúmeros traumas que fizeram parte desses tempos. Duas guerras mundiais, genocídios, conflitos armados, bombas atômicas, campos de concentração são termos que invariavelmente tornaram-se sinônimos dessa era dos extremos (HOBSBAWM, 1995).

Sobre essa dimensão traumática, Márcio Seligmann-Silva lembra uma reflexão de Primo Levi, autor que posiciona o testemunho como "condição de sobrevivência" do sujeito que narra na medida em que amplia "para outros" a experiência vivenciada. Ainda segundo Seligmann-Silva, o testemunho é intrigante por conjugar sentimentos difusos e poderosos, o que fez com que, no que tange propriamente aos traumas, o gênero fosse visto com desconfiança por facilmente deslizar às teias da imaginação, estratégia muitas vezes utilizada como forma de se trabalhar assuntos considerados inenarráveis por seu grau de violência e subjugação. Haveria ainda um aspecto paradoxal no ato testemunhal, que é a sua singularidade. Todo "testemunho 
é único e insubstituível", uma "singularidade absoluta" que "condiz com a singularidade da sua mensagem. Ele anuncia algo excepcional". Por seu turno, "é esta mesma singularidade que vai corroer sua relação com o simbólico" uma vez que a "linguagem é um constructo de generalidades [...] feita de universais". O testemunho torna-se, então, um "evento particular" que "desafia a linguagem e o ouvinte". (SELIGMANN-SILVA, 2008, p. 66-72). Não em vão, o testemunho ser visto com reservas quase que insuperáveis no âmbito jurídico, o que, a depender do objeto, não deve ser ignorado pelo historiador.

Para o propósito principal desse texto, que tem o âmbito religioso como central, importa outra dimensão essencial do testemunho, a sua ambição pela exemplaridade. Todo ato testemunhal ambiciona essa condição. A etimologia deixa mais clara tal inclinação, embora haja imprecisão quanto à raiz precisa do vocábulo atual. O linguista e etimólogo Emile Benveniste aponta dois termos como condizentes ao sentido contemporâneo: testis e superstes. O primeiro, de origem latina, significaria “aquele que assiste como um 'terceiro' (terstis) a um caso em que dois personagens estão envolvidos". O segundo, também latino, sugere outro tipo de testemunha, mais precisamente aquela “"que subsiste além de', testemunha ao mesmo tempo sobrevivente, seja como 'aquele que se mantém no fato', que está aí presente” (BENVENISTE, 1995, p. 278).

A segunda acepção é providencial para se pensar a problematização do presente texto. Desde o início do cristianismo, o ato do testemunho assumiu centralidade. Pelas condições impostas pelo Império Romano, para os primeiros cristãos "testemunhar" consagrou-se como um dos valores mais caros ao grupo, pois, ainda que significasse a possibilidade da morte, garantiria a sobrevivência da comunidade. Em grego, a palavra "testemunho" revela essa proximidade até o presente uma vez que se escreve " $\mu \alpha \rho \tau v \rho i ́ \alpha "$ (martyria) e significa "a capacidade de entrar em uma relação interpessoal com base na narração de um fato", sendo "expressão privilegiada da linguagem humana porque cria atos concretos que a palavra falada por si só não é capaz de indicar" (FISICHELLA, 2003, p. 751). Mais além, tanto em sua raiz latina, superstes, quanto na grega, martyria, o testemunho apresenta-se como "para além da fala", como linguagem performativa que exige do sujeito o empenho da própria vida e da sua honra pessoal.

Não obstante, a Bíblia é farta de menções testemunhais, as quais são apresentadas sob três eixos fundantes: revelação, transmissão e credibilidade. É tal tríade que substantiva a divindade de Cristo mediante ao fato religioso da ressureição. O evangelho de João é concluído pelas seguintes palavras: "Este é o discípulo que dá testemunho de todas essas coisas, e as 
escreveu" (Jo 21,24). O livro dos Atos dos Apóstolos é iniciado apresentando os apóstolos como as primeiras testemunhas. Em Atos 1,8 Cristo demanda: “descerá sob vós o Espírito Santo e vos dará força; e sereis minhas testemunhas em Jerusalém, em toda Judeia e Samaria e até aos confins do mundo". O sacramento do Batismo teologicamente consagra o cristão a ser parte de uma corrente testemunhal universal com status de missão histórica (FISICHELLA, 2003, p. 751-752).

Nesse sentido, conforme já pontuado, o autorreconhecimento do entrevistado como "testemunhante" não foi aleatório já que demarca um lugar social historicamente forjado. Primeiramente, trata-se de um recurso tanto para posicioná-lo no interior do campo religioso católico quanto para garantir-lhe legitimidade em relação a quem o questionava. Mas há mais a ser observado. O relato/testemunho, nessa ocasião, recorre a referências anteriores, eclesiais e cotidianas, que assumem grau de verdade diante de muitos interlocutores. Entre esses: o pesquisador, a comunidade presente no santuário ou gruta e um terceiro sujeito, o qual sempre estaria presente nos espaços de religiosidade - a divindade. Nesse cenário específico, emergem estratégias para demonstrar ao entrevistador que não ocorreria uma "interlocução padrão", pois há intenções e profissões de fé em curso. Com efeito, o verbal prolonga-se para uma dimensão existencial e o binômio "verdade/mentira" deixa de fazer sentido uma vez que haveria uma testemunha invisível, sempre presente e inescapável.

Nesses termos, o "fato religioso" que se está narrando não pode ser reduzido a fórmulas verbais padrão. Há muito de sensibilidade e imperam leituras revestidas do que teologicamente denomina-se como "mistério" - o que acaba por deslocar a fala sobre o que teria ocorrido para uma dimensão da experiência (HIGUET, 1984, p. 21). Em síntese, como isso é arranjado em termos de organização narrativa é o que será analisado nos próximos tópicos.

\section{A presença de um ausente: a divindade como personagem}

As narrativas elaboradas pelos entrevistados, as fontes orais propriamente, são dotadas de características próprias, de singularidades importantes. Tais propriedades derivam justamente da capacidade humana da faculdade da memória, um fenômeno neuropsíquico complexo que serve para que os sujeitos expressem o que são e como isso forja as suas “identidades". Para o antropólogo Joël Candau, a memória constitui-se sob três dimensões, as quais escalonadas em função do esforço mental necessário para evocá-las, organizá-las e, por fim, transmiti-las. São essas: 
1) A protomemória, uma "memória de baixo nível", que "constitui os saberes e as experiências mais resistentes e mais bem compartilhadas pelos membros de uma sociedade", uma "memória incorporada", "gravada na carne" por "múltiplas aprendizagens adquiridas na infância e mesmo durante a vida intrauterina". As ciências humanas há tempos vêm se debruçando sobre essa dimensão da memória, o qual foi pensada por conceitos como "ethos" e “habitus". 2) A "memória propriamente" dita, ou de "alto nível”, "que é essencialmente uma memória de recordação ou reconhecimento", que funciona pela evocação deliberada ou involuntária de "lembranças autobiográficas ou pertencentes a uma memória enciclopédica (saberes, crenças, sensações, sentimentos etc.)". Esse nível intermediário também se faz de esquecimentos e "pode beneficiar-se de extensões artificiais que derivam do fenômeno geral da expansão da memória". 3) Por fim, a metamemória "que é, por um lado, a representação que cada indivíduo faz de sua própria memória, o conhecimento que tem dela e, de outro, o que diz dela”. É nesse nível que ocorre a “construção explícita da identidade”, pois é nesse ponto que o indivíduo se remete às suas afiliações ao passado (CANDAU, 2011, p. 21-23).

A partir dessas definições, importa lembrar que são os dois primeiros níveis os que mais são mobilizados no cotidiano. A interação de ambos proporciona os predicados necessários para organizar o complexo conjunto informações que o sujeito mobiliza de forma coerente e inteligível ao interlocutor, desde o arranjo das partes da narração até mesmo os gestos que comumente compõem a performatização do que é narrado. Há muitos outros, mas são exemplos protomemoriais gestuais muito comuns a elevação do dedo indicador ao alto quando os entrevistados se referem às divindades, sobretudo o termo Deus, e a junção das mãos junto ao peito quando há menções às rotinas diárias de oração e ritualização. Embora os âmbitos gestual e imagético não sejam propriamente os objetos desse texto, eles nos ajudam a compreender o posicionamento da divindade como parte ativa e presente nas narrativas de memória. A sagração do "momento ritual", expressão cíclica, periódica, e, portanto, religiosa do espaço e do tempo colabora nesse sentido (ELIADE, 1997, p. 482).

A performatização dos movimentos evidencia o poder de mobilização social uma vez que narrar com intensidade e vivacidade configura-se como um dos produtos dessa interrelação. Devido à sacralidade, torna-se imperativo revestir o que se narra de uma aura extra-humana e, deste modo, afirmar que ali não se fala de experiências comuns, mas de acontecimentos extraordinários e excepcionais - o que remete à unicidade do testemunho, referida nas reflexões desenvolvidas inicialmente. Sendo que os acontecimentos são incomuns, resta a garantia pessoal do acontecido. No âmbito religioso, a fidelidade à comunidade de sentidos e 
sentimentos posta em santuários, grutas e outros espaços apresenta um peso significativo. Tal lealdade inclina os indivíduos à noção de que cada um torna-se uma expressão a mais da efetividade da divindade, elemento do qual o pesquisador não escapa na medida em que participa da ocasião. Testemunhar, ainda que o ato seja apenas estar presente, é uma obrigação. A força da fala e do gesto é projetada para dimensões que fugiriam do controlável. O próprio pesquisador é atirado nessas teias, algo que surpreendeu na declaração que evocou o ato testemunhal. Mas ela não foi a única, conforme se percebe pelo trecho a seguir:

Pesquisador: O senhor autoriza... eu usar esse depoimento para o meu trabalho, para analisar, enfim?

Entrevistado: Não, pode... Mas o senhor mora aqui em Santa Izabel? Pesquisador: Não, em Marechal Cândido Rondon, é lá que eu estudo.

Entrevista: Mas olha... pode. Eu vou dizer... Se tu usa aqui e amanhã ou depois me "canetiá" [criticar], eu sei que você é perante Nossa Senhora Aparecida aqui no santuário. Nossa Senhora Aparecida tá enxergando... Olha aí ó!" (Entrevista com Z., J., 2012).

A fala demarca que os liames da significação religiosa são, teoricamente, infinitos. Ainda que não haja uma fundamentação teológica propriamente dita nas sentenças, há clareza sobre o que seria o sagrado e, portanto, o profano. Embora o pesquisador queira transpassar as noções de objetividade, de rigor analítico, de compromisso ético com quem se fala, na ocasião do relato tais valores foram tidos como secundários, de relevância menor. Nesses termos, qualquer assinatura ou compromisso formal seriam de menor relevância ou até mesmo desimportantes. Ainda que tenha havido desconfianças quanto à cessão da fala para a análise ou mesmo se a entrevista seria utilizada para bons propósitos, a evocação da divindade adentra no diálogo como garantia de um pacto forjado entre os sujeitos comunicantes. A distinção estaria no "lugar de fala" e nas legitimidades que cada um deles apresenta. Um é humano e perecível; o outro é ligado ao eterno e ao inescapável. O alerta é emblemático nesse sentido: do julgamento da divindade não haveria fuga ou esquiva possível, pois estaria para além do verbal e no âmago da consciência.

Entre os fiéis há um consenso: as divindades habitam no lugar religioso e por meio dele se projetam no mundo por meio de proteções, graças e desígnios para o porvir. Elas são, por assim dizer, as verdadeiras senhoras da história humana. Nesses espaços, as possibilidades de abertura pessoal para com os demais, momentaneamente seus iguais, são ampliadas e buscadas. Não parece haver receios significativos em permitir que angústias e sofrimentos cotidianos sejam visualizados e reconhecidos, pois são os motivos de se estar ali, são as provas de que outras forças atuam de forma ativa no mundo material. Por essas razões, não é necessário insistir 
para que os indivíduos falem. Quando uma entrevista é finalizada já há outra pessoa observando, fitando timidamente e, de certa forma, pedindo para ser ouvida. Nas faces de quem aguarda é possível observar a expressão do esforço mental e a preparação das palavras para expor de forma digna e orgulhosa o que se passou, o quanto a santidade é efetiva e, o mais importante, a razão de se estar ali. A operação de testemunhar e se expor, porém, aparenta tornar o narrador mais leve, como se o verbalizar das aflições fosse um recurso a mais para que a divindade lhe olhe com carinho.

As peregrinações são dotadas de alto grau performático. Isso se dá por sua capacidade de emular experiências pessoais intensas em períodos curtos temporalmente - fenômeno que o antropólogo Victor Turner observa em várias sociedades e momentos históricos e que ele categoriza a partir do conceito de "communitas" - união provisória "entre indivíduos concretos, históricos e idiossincráticos". Segundo Turner, "a espontaneidade e imediatidade da “communitas"” opõem-se "ao caráter jurídico e político da estrutura", pois raramente consegue ser mantida por muito tempo. Entre os diferentes tipos de communitas, os rituais religiosos seriam um "tipo existencial" de associação uma vez que suspendem o tempo cotidiano e proporcionam o "perdão mútuo dos defeitos de cada um” (TURNER, 1974, p. 161).

Os efeitos do poder ritual são enormes e dialogam intimamente com os valores religiosos que se materializam no lugar ou ocasião. $O$ cristianismo tem um conjunto de vocábulos que marcam a sua estrutura sociorreligiosa: graça e agradecimento são os mais comuns, mas há muitos outros. Não raro, tal como em uma confissão, o entrevistado reconhece as suas faltas, emociona-se, cai em prantos e, por meio do interlocutor, pede perdão pelas faltas cotidianas. Exteriorizar pelo testemunho é fator de aproximação com a divindade e, portanto, um elemento a mais para o que se busca, que é a graça que remediaria a pequenez que nos seria característica enquanto seres humanos. Entre os casos, merece atenção o seguinte trecho:

A fé que eu tenho, eu falo bem a verdade mesmo. Eu falo bem a verdade. A fé minha é que eu não quero mais batê nessa esposa minha. Eu bati nela. Várias vezes. Eu quero pedir essa fé, entendeu? Porque se ela fosse uma pessoa que não gostasse de mim, ela não taria comigo [chorando]. Tá me entendendo? Essa é minha fé, porque eu quero tirá mesmo. Eu pra mim eu quero conseguir. Porque eu conheço ela há nove anos e eu não sei porque quando eu bebo os meus goles - posso falar tudo? [olha para a companheira pedindo-lhe autorização]... ela é uma pessoa inocente e eu faço "cagada" quando chego em casa. E ela nunca fez nada pra mim. O meu braço tá aqui, por esse motivo. Um dia antes da eleição ela foi pra casa, bem quietinha e dormiu, mas ela é sãozinha. E eu fiquei bebendo, discutindo. Daí cheguei em casa, bati na porta, na janela, e ela não escutou. Digo: - agora vou abrir a porta. Daí eu meti a mão na porta. Por isso que eu tô com o braço desse jeito [ergue o braço que 
está enfaixado], meu rosto arranhado é de caco de vidro. Eu quero pedir que tire de mim. Com toda a razão! (Entrevista com N., L., 2012).

Entre outros fatores, a confiança na clemência divina é proporcionada pelas dinâmicas do espaço de religiosidade: são tantas afirmações aparentemente concretas de que a intercessão divina atua no mundo, tantas emoções suscitadas, que tudo parece possível: "Nossa Senhora há de me olhar". Durante as entrevistas, quem fala faz questão de narrar os caminhos e descaminhos percorridos, as preparações pessoais, as organizações entre amigos e colegas, os cronogramas anuais de frequência ao santuário e outros lugares, os dispêndios financeiros para pagar despesas de viagem e, a parte mais tocante em termos de performance ritual, os sacrifícios corporais dispendidos na peregrinação até o lugar religioso e a romaria propriamente dita. Segue um relato nesse sentido, o qual recorre à tal estrutura narrativa:

[Ao ser questionado sobre a peregrinação] Eu venho aqui desde 1980 e poucos. Quase no comecinho. Sempre a pé. Não venho pedir, eu venho agradecer. [...] No começo eu vinha com um monte de gente. Como é promessa eu nunca parei. Até doente eu já vim. Uma vez até paguei um rapaz pra vim comigo.

Pesquisador: Mas o que mais o senhor pede, agradece?

Entrevistado: A gente sempre quer saúde né, porque, como diz o outro "o resto a gente corre atrás". Os meus piás [meninos] vêm e eu sempre disse que é bom, te renova, não faz mal nenhum. E o que que é três, quatro, cinco horas de caminhada? Deus dá tanto pra nós! (Entrevista com L., T., 2013).

$\mathrm{Na}$ fala, impera as noções de compromisso e agradecimento. O entrevistado reafirma os seus laços com a divindade pela periodicidade das rotinas, provações ao seu corpo físico e, como consequência, o reforço da espiritualidade. Retoma-se, assim, elementos protomemoriais, impressos entre marcas e cicatrizes atestadoras do vínculo entre o fiel, a sua comunidade religiosa e a divindade de sua preferência. Notadamente, ainda que a prática em si seja idiossincrática, estruturas comportamentais historicamente constituídas são reencenadas fornecendo modelos para que o fiel imprima as suas particularidades aos atos. No caso preciso do cristianismo, por sua centralidade oficialista no decorrer dos séculos, tal característica é quase um padrão, vide a origem do termo "romaria" que significa "peregrinação à Roma". No mundo ibérico, a peregrinação via romarias tornou-se uma prática ritual consagrada para materializar a fé e os laços com as divindades, atos que no Brasil são amplamente reconhecidos pelos termos "promessa" e "graça".

É notório que o ato de ir até os lugares onde morariam, estariam posicionados ou se manifestariam os "seres sagrados", é feito pela humanidade desde tempos imemoriais (ASSMANN, 2011, p. 322). No cristianismo, devido à sua raiz semítica abraâmica, a 
peregrinação reafirma uma aliança solidamente fundamentada na Bíblia, sobretudo no Antigo Testamento. O livro do Êxodo é paradigmático no sentido de asseverar a aliança com Deus pelo caminhar, um ato sacrificial que deu origem ao Povo de Israel como categoria e uma via para expiar o "pecado original" de cada um dos seus membros. Nesses termos, o inevitável ato de pecar poderia ser remediado pelo ato sacrificial constante posto no movimento até Deus. A figura de Cristo, o novo Cordeiro de Deus, inseriu elementos que ressignificaram historicamente tal aliança na medida em que, pelo ritual da missa, periodicamente reencena-se a Paixão, afirmada no Evangelho de Lucas em termos mnemônicos: “fazei isso em memória de mim”. O cristão, então, precisaria ir até onde está o seu Deus (HATTSTEIN, 2000).

Importa reconhecer que tais reflexões são de natureza eminentemente teológica, ou seja, contam com leituras cujas minúcias não necessariamente são mobilizadas integral e cotidianamente pelos fiéis. Contudo, ainda que fragmentariamente e mesmo que o sujeito se julgue "não praticante", noções surgem e ressurgem entre as falas e gestos, algo que reflete o vínculo pessoal com o sistema religioso do qual se fala. As religiões constituem-se mediante uma série de ritos de passagem e o cristianismo é exemplar nesse sentido, pois apregoa a manutenção sacramental desde os primeiros momentos da vida. Nesse ínterim há um processo de formação em curso, algo que está presente na narrativa anterior. Ao cristão seria necessário reconhecer a sua pequenez, compreender o que pode ser feito para afirmá-la diante do que seria eterno e, por fim, cumprir com as suas obrigações pessoais. Assim, a confirmação da ação da divindade na vida se dá pelo próprio peregrinar: "se aqui estou, são, salvo, como explicar isso senão por razões extra-humanas?”.

Com efeito, o auto sacrifício como fator dignificante das práticas de religiosidade é uma das noções mais comuns na organização narrativa. Em geral, até a narração sobre as provações e graças recebidas há uma composição padronizada: inicia-se com um elogio ao espaço do santuário, fala-se da beleza de se ver os demais fiéis em estado de êxtase e sobre quão renovadora é a experiência de se estar ali. A partir disso desliza-se para falas autocentradas e reflexivas sobre a própria existência. Não raro apela-se para o reconhecimento do entrevistador: “o senhor acredita que algo assim seja possível?". Atestar o sofrer e vivê-lo de bom grado aproxima o fiel da graça a ser alcançada ao passo que legitima o sujeito de religiosidade no presente. Nessa esteira, os dons advindos da divindade raramente são quantificados precisamente, pois dá-se a ideia de que se diluem de formas tão diversificadas no dia a dia que a própria vida se torna pequena para acomodar as graças alcançadas e os agradecimentos necessários diante dessas. Tal leitura aparece em relatos como o que se segue: 
[rezo] lutando com as minhas coisas no dia a dia. Até o meu marido fala assim: "porque tu reza muito?". Eu falei: "não é muito, é muito pouco". Eu digo para ele, porque eu sei que quanto mais eu ajudo Deus, Deus me dá mais (Entrevista com N., C., 2012).

A promessa e o pagamento dela são os principais reconhecimentos de que a divindade fez e fará parte da vida do fiel (FERNANDES, 1994, p. 158). Nesse ínterim, existe uma certeza: "Deus é muito bom, muito melhor do que merecemos e agradecê-lo nunca é demais". Pedir, por sua vez, emerge como algo secundário e, a depender, até mesmo indigno. Entre os consultados, houve uma quase unanimidade em torno dos pedidos e agradecimentos em relação à manutenção do corpo e à saúde, algo presente em uma das entrevistas anteriormente citadas. Ao mesmo tempo, há uma ausência total de menções a questões financeiras. Aliás, nos momentos nos quais tal ponto foi levantado pelo entrevistador houve a relação dessa busca com as denominações evangélicas, as quais são apontadas como pessoas de "fé fraca", pois facilmente iludidos por promessas de "ganho fácil" e "felicidade".

A díade "sofrer/agradecer", portanto, é uma constante e há nisso elementos de longa duração sendo evidenciados. Entre outros motivos, o sofrer é consagrador na medida em que aproxima o fiel do paradigma da Paixão de Jesus Cristo e da via-crúcis, algo evidenciado em estudos que tematizam outras romarias (STEIL, 1996, p. 97). O entendimento de que o sofrimento é parte constituinte das práticas religiosas dignifica os fiéis e eleva as suas demandas. Há, porém, uma ressalva muito importante. Quaisquer comparações entre o próprio drama e o de Cristo ou de Nossa Senhora são prontamente rechaçadas, pois "eles sofreram muito mais", são exemplos a serem seguidos nesse sentido. Em comparação com as divindades, os fiéis apresentam-se como minúsculos e imperfeitos.

A condição humana é pensada constantemente nos locais de devoção. No geral, aceitase que viver é, de certa forma, padecer pelas agruras da vida, pelas falhas, sofrimentos, limites pessoais, erros diários e fragilidades dos corpos, os quais castigados pelo tempo, pelas dores e deformações. Os pedidos variam e se renovam entre uma miríade de inquietações pessoais e necessidades prementes. Não há um critério para tanto, pois são elementos que dialogam com os dramas de cada um. Os pedidos vão desde a singela requisição de um dos presentes que, constrangido, afirmou estar ali para que Nossa Senhora lhe arrumasse "uma companheira", até mesmo o agradecimento pela preservação da própria vida ou de um familiar. A fala a seguir, por exemplo, foi proferida por um senhor que tinha vindo da cidade de Oberá, Argentina, e relata o seu percurso de encontros e desencontros cotidianos com a vida: 
Entrevistado: Sou fã dessa virgem faz oito anos e... a única virgem que visitei até agora foi ela. Fui uma vez a Luján em Buenos Aires, que me disse minha filha, e depois não fui mais em outra virgem. [Soube da Romaria] por intermédio de um amigo daqui de Santo Antônio do Sudoeste. Aí vim conhecer um dia no... ano de dois mil e cinco e daí não deixei de vir todo ano, todo ano eu venho. [A razão] É... uma é que eu tomava bastante, tinha amigos e tomava cerveja e um monte coisas. Então fui pedindo à virgem que me tirasse disso e graças a Deus. Sabe que ela me tirou!? Me tirou, realmente me tirou disso, realmente me tirou disso, não deixei minha amizade, mas deixei da bebida. Sou mais familiar e, bom, estou tranquilo.

Pesquisador: E na Igreja, o senhor vai?

Entrevistado: Pouco, pouco, pouco! Tenho que ir mais.

Pesquisador: A sua relação é mais com a virgem então?

Entrevistado: Tenho a imagem dela em minha casa e sempre me sento me ajoelho e rezo diante dela, que é outra coisa. Neste ano trago um amigo com a senhora dele e cada ano trago outro para que me acompanhe. E, bom, ele gostou!

Pesquisador: O senhor participa de outra igreja?

Entrevistado: Não, não, só da católica! Sou mais romeiro que de Igreja, claro! (Entrevista com G., R., 2012).

Entre outros elementos, o narrador faz questão de pontuar os acontecimentos que teriam feito a sua visão mudar a respeito dos seus hábitos. Há os que precisariam da intercessão para dar conta de situações-limite, mas não raro aparecem os que querem testemunhar a respeito de como a vida pode sair do controle. No caso, o hábito de beber estaria lhe causando dissabores e separando-o da família. Segundo o entrevistado, ele esporadicamente ainda bebia, mas agora com o entendimento de que seria necessário um "valor maior" que lhe acompanhasse, que lhe lembrasse do que realmente importa. Tem-se, portanto, a expressão da religião enquanto elemento que reordena um mundo que se desordenou, que permite a superação do estado de "anomia" ao qual o fiel está submetido. Notadamente, para os propósitos desse texto, importa pensar a forma como o entrevistado se insere em uma corrente testemunhal que aumenta ano a ano. Muito provavelmente ele dedica parte do seu tempo com os amigos falando sobre o que lhe teria acontecido, o quão efetiva é a "virgem" e os novos sentidos construídos por ele a respeito dos hábitos que mantinha anteriormente. Engrossar a fileira de romeiros para ele é tão importante quanto ajoelhar-se diante da imagem. É, inclusive, muito mais central do que frequentar o espaço da igreja - o qual mais rígido liturgicamente e, portanto, autocentrado na figura do padre. A cena de pessoas indo e vindo, mesmo no meio das missas, sugere que, nos santuários, talvez a maioria busque a intimidade e a relação imediata com a santidade. A fila para tocar na imagem, fazer uma pequena oração ou depositar um pedido ou agradecimento na caixinha que fica na lateral da gruta, é gigantesca. 
No processo como um todo os fiéis testam seus limites corporais - tanto na fila, quanto entre as muitas práticas de aproximação com o santuário, que acontecem desde dois dias anteriores ao evento de 12 de outubro. São peregrinos que afirmam ter percorrido as mais variadas distâncias a pé. A depender das condições físicas, um quilômetro pode parecer uma centena. Observa-se pessoas em marcha, portando muletas e outros sinais de limitação física, em prantos. Pessoas andando de costas. Outros percorrendo os últimos metros até lá de joelhos. A ideia é mostrar que a fé lhes dá força e que a vulnerabilidade humana é pequena ante a resistência que a divindade proporciona, o que é tido como mais uma graça alcançada. Pelo narrar afirma-se que não seria possível estar ali apenas por fatores materiais - raciocínio que serve para constituir a prova da força da aliança com as divindades.

A dramaticidade das ocasiões narradas é comumente proporcional à intensidade do agradecimento. Diante do que poderia ter sido, a divindade teria feito muito. Sem ela, seria muito pior. Uma narração muito tocante nesse sentido partiu de uma senhora que, ao ser abordada, apresentou a sua filha, uma mulher de 41 anos que desde os cinco anos de idade encontrava-se acamada e incapaz de falar ou comunicar-se minimamente. A filha encontravase deitada, na sombra de uma das árvores, tendo a mãe como vigia. Segundo a senhora, "sem nunca ter falhado um ano" ela trazia a filha ao santuário há 21 anos. Ao ser questionada sobre a motivação que lhe trazia, a resposta foi simples:

Entrevistador: Então a senhora participa porque Nossa Senhora proporcionou uma graça para a senhora?

Entrevistada: A graça é que ela tá aqui com nóis ainda. E tem meu filho que sofre do coração. Não, tem um filho que sofre do coração e eu vim aqui pedir pra ela ajudar que ele sare do coração. [...]. A minha fé vale mais do que tudo... eu que tenho por Ela, porque Ela trouxe ela pra mim.

[...] Entrevistado: E sempre devotos?

Entrevistada: Sempre. Isso nóis só vai abandonar depois que Ela [Nossa Senhora] vim buscar nós. Daí nós deixamos de ser devotos. (Entrevista com S., N., 2012).

A entrevistada faz questão de posicionar a intercessão como a única explicação possível diante da dramaticidade da doença da filha: "não tem explicação!". Embora a situação fosse precária, sem Nossa Senhora o que seria? A fragilidade da vida também é colocada na menção ao filho, que sofreria de um mal no coração que precisaria ser curado e assim seria. A despeito de ambos os problemas, existe a certeza de que houve a manutenção da vida filha pela ação da santidade - "quando eu ia indo com ela morta nos braços, longe de a pé [...] já numa altura eu me atirava de joelho na estrada e pedia que Nossa Senhora da Aparecida tivesse junto com nós e salvasse ela pra nós". A memória reconstrói uma situação que lhe teria levado a sucumbir 
diante dos males do mundo. Ao "atirar-se" no chão em um movimento de súplica, de mãe humana para mãe divina, apresenta-se a "piedade infinita" da divindade que minoraria todos os males e pode vencer o maior de todos, que é a morte. A aliança da devota então é garantida até o final da vida: só deixarei de ser uma quando morrer!

A questão da saúde, estabelecida no relato anterior, merece uma maior atenção, notadamente pela frequência com a qual tal elemento aparece. Com o corpo em dia, pode-se trabalhar, levar a vida adiante e, inclusive, estar no santuário para agradecer mais um período de bem-estar. Nesse ínterim, emergem afirmações que soam como objeções e desafios ao saber humano. Haveria uma limitação insuperável do saber médico que, embora seja apresentado como um "presente de Deus", é apenas “desse mundo". Uma das menções mais comuns nesse sentido é a ocasião do "desengano do médico", quando as vias do mundo se esgotam e não haveria mais ao que recorrer. Nesse momento, restaria ao sujeito conformar-se com a fatalidade da morte ou com a limitação física permanente: “está nas mãos de Deus”. É o que aparece na fala a seguir:

[Ao ser questionado de o porquê ter vindo]. É promessa! Quando eu trabalhava numa firma em Capanema eu finquei um prego e no joelho direito. Fui ao hospital e nada de curar. Aí o doutor falou assim: "tenho que cortar a tua perna em Beltrão". Eu disse: "eu nasci com as duas pernas e vou morrer com as duas pernas". Então, diz: "o senhor de agora em diante não precisa mais ficar no hospital, pode ir pra casa". Aí eu saí do hospital, peguei um taxi e fui para casa. Eu disse: "Nossa Senhora Aparecida, me ajude. Se eu sarar, é promessa". Então é todo dia 12, chove ou não chove eu venho de a pé. Trouxemos um lanchinho eu e meu vizinho, almoçamos, fiquemos por aí. Se tem transporte nós vamos, se não nós vamos de a pé para casa (Entrevista com Z., J., 2012).

É nos limites da vida, como um último recurso, que a divindade se apresentaria. É contrariando as expectativas, nas horas mais extremas, que a divindade atuaria de fato no mundo. A sua presença serve para, justamente, contrariar as visões teoricamente limitadas de quem enxergaria o corpo humano apenas como um corpo físico. Os fiéis não separam o corpo do espírito, o que faz com que a medicina e outros saberes em alguns momentos possam ser equiparados com benzimentos e outras práticas. Ao fiel, são métodos que servem ao propósito da cura. Tal como afirma o antropólogo Rubem César Fernandes, nesses casos a medicina é "boa enquanto funciona, mas incerta no final das contas". Assim, não haveria motivos para "entregar-se a ela de corpo e alma. Mesmo a intervenção mais simples, que seja na cadeira do dentista, carece de uma oração" (FERNANDES, 1994, p. 163).

Nesse sentido, entre significações e ressignificações que as alianças mais duradouras são alinhavadas entre o fiel e a sua santidade de preferência, o que gera o círculo contínuo de 
práticas rituais e de testemunhos. Entre promessas e pagamentos que podem ser grandiosas, existe a compreensão de que a divindade é efetiva no que garantiu, mas compreensiva e piedosa na cobrança. As práticas intimistas permitem a relativização das promessas. O contrato está no âmago da memória e pode ser reatualizado na medida em que as circunstâncias exijam. Um percurso a pé pode ser substituído por uma doação ao santuário ou por uma rotina de orações. A ida anual, prometida há muito tempo, se não possível, pode ser cambiada por uma ida à um local de devoção mais próximo, uma gruta interiorana. O importante seria fazer algo, compensar a graça pela saída da inércia. Em síntese, faz-se o que se pode e a divindade há de compreender. Tais elementos aparecem na narrativa a seguir:

[relata o momento do acidente do filho e conclui] daí eu falei, se ele melhorasse e ele voltasse para casa nós ia vir dali oito dias depois trazer um vazo de flor. Mas daí eu achei melhor trazer hoje e fazer a contribuição que eu pudesse, até trouxe uns docinhos para colaborar com o santuário. Daí eles me deram um presentinho e eu disse que não queria presentinho porque o presente maior Nossa Senhora me deu, né (N., C., 2012).

A ida e a vinda encerram um ciclo, mas inicia muitos outros. Embora as insuficiências sejam reconhecidas, há uma marcha em curso a qual ambiciona a redenção e, por que não, a santidade. A consciência parece ficar mais leve na medida em que o fiel faz o que teria que ser feito, ainda que as vezes isso ocorra de forma um tanto quanto "torta". Não se estaria "tapeando" a divindade, mas garantindo o cumprimento de algo que se estende para além da vida. Assim como ela não abandonaria os seus devotos, também eles não deixam de "estar ali", de falar para todos que conhecem que existe efetividade na fé e na repetição das rotinas. Fazer da própria vida um ato testemunhal constante, que sacraliza o dia a dia, torna-se uma obrigação. A redenção vem na medida em que se vive e se conduz o cotidiano entre as rezas, os trabalhos habituais, as falhas constantes, os reconhecimentos. Até mesmo no praguejar e na impaciência pela demora das graças há algo de testemunhal, pois embora aparentemente o fiel esteja "abandonado", a divindade restitui o otimismo. A fala que se segue estabelece essa interrelação e exacerba o senso de fidelidade que sacraliza os muitos momentos da vida do romeiro. Não obstante, visualiza-se uma enorme segurança existencial a qual converge para um profundo autoabandono em relação aos mistérios do mundo:

Desde os oito anos eu rezo o rosário e nunca vou desistir. Até meu pai era crente e ele dizia assim: "vamos mudar". Mas daí eu dizia: "não pai, porque eu sou muito feliz na minha religião e vou morrer com essa". Todo dia de manhã, às seis horas eu vou pra móde rezar o rosário. E isso para mim é sagrado. Se eu vou sair eu vou rezando na estrada e onde que eu tô, eu tô 
rezando. Seis horas da manhã eu já entrego a minha família na mão de Nossa Senhora para tomar conta (Entrevista com N., C., 2012).

\section{Considerações finais:}

Para encaminhar as reflexões finais, destaca-se a fala proferida por uma garota que naquele momento tinha apenas 17 de anos de idade. Ela foi abordada no santuário devido à emoção que demonstrava. Mesmo que em prantos, quis falar ao ser solicitada. Dada a sua dificuldade em discorrer, foi necessário esperar que ela se recompusesse para que a gravação fosse iniciada:

\footnotetext{
Pesquisador: você se considera uma devota?

Entrevistada: sim, bastante.

Pesquisador: me explica isso...
}

Entrevistada: Eu... como eu vou te explicar? Não tem como explicar. É um sentimento que você tem, que te chama para um santo que você pode conversar. É como se você tivesse uma conversa direta como ele mesmo. Mais ou menos isso (Entrevista com M., D., 2012).

De várias formas, a fala anterior exprime as linhas centrais que pautaram as reflexões desse texto. Sendo mais preciso, o ponto de partida foi a problematização acerca das diferentes maneiras como fiéis, "sujeitos de religiosidade", mobilizaram mnemonicamente gramáticas significativas por meio de narrativas testemunhais. Tal exercício lhes muniu, subjetiva e intersubjetivamente, para organizar e verbalizar as suas práticas de devoção, tendo em vista um compromisso que estaria para além do exercício puramente descritivo.

Como eixo basilar, pensou-se como tais operações posicionaram as divindades como personagens que interfeririam objetivamente na história cotidiana dos entrevistados. Entre as reflexões, tematizou-se como, no santuário, ativam-se vetores de valorações que percorrem a constituição do narrar e interferem ampliando os nortes para a interpretação dos acontecimentos. Da mesma forma, como experiências pessoais, elementos confirmativos, traumas, pedidos, agradecimentos etc., são mobilizados para assegurar a exemplaridade do que se faz e do porquê se faz, uma característica do ato testemunhal.

Com efeito, o "fenômeno religioso", entre outras características, materializa-se por meio dos indivíduos que lhe dão sentido. Quando as experiências pessoais de religiosidade são narradas, observa-se um campo de tensões e socializações percorrer o lugar de maneira relacional. É fato que não há como definir o sentido preciso de uma experiência ou escolha, mas é possível pensar os critérios de legitimidade utilizados por quem narra para justificar o que se faz e como se faz. Nesse ponto em específico, mais uma vez a categoria "testemunho" foi muito útil, pois embora haja emoções candentes à vista, nos lugares de religiosidade é 
possível notar um esforço profundamente racional que ambiciona a construção de narrativas que possam transcender a mera descrição de acontecimentos.

Há, por essas razões, muito de existencial no que se expõe, o que sugere que, para além de se descrever o que houve, existe a tentativa de demonstrar que há sentidos maiores envolvidos, os quais compreensíveis e legitimadores dos atos “de quem tem fé”. Existe, nesses termos, muito de comunidade nisso tudo, ainda que o testemunho ambicione unicidade e exemplaridade. Na medida em que o fiel se utiliza dos sinais do corpo e da subjetividade da memória para testemunhar; expor a igualdade humana que emana das próprias limitações e a dos seus; afirmar as graças buscadas e alcançadas; chorar por suas realizações e emocionar-se pelas dos demais; os sujeitos desnudam as múltiplas interdependências que percorrem a vida humana. Notadamente, pelo aspecto dinâmico das romarias, há um sentido de percurso nesse processo: de onde vim, onde estou, para onde vou.

Entre partidas e chegadas, o lugar de religiosidade pode ser pensado tanto pelas suas partes (as particularidades dos testemunhos em si) quanto pelo todo, ou seja, como um grande ato testemunhal coletivo. Entre outros pontos, o caráter assertivo dos fiéis reside na quase que inabalável certeza de que a vida não acaba na materialidade, seja por parecer pequena perto da aparente infinitude do poder divino, exposto inclusive na beleza e emoção exposta no santuário, ou mesmo pela constatação de que o "plano terreno" é tão eivado de sofrimentos e provações que se torna difícil aceitar que acabe nele mesmo.

\section{REFERÊNCIAS}

ASSMANN, Aleida. Espaços da recordação: formas e transformações da memória cultural. Campinas: Editora da UNICAMP, 2011.

FERNANDES, Rubem César. As romarias da paixão. Rio de Janeiro: Rocco, 1994.

FISICHELlA, Rino. Testemunho. In: LEXICON: DICIONÁRIO TEOLÓGICOENCICLOPÉDICO. Trad. João Paixão Neto; Alda da Anunciação Machado. São Paulo: Edições Loyola, 2003, p. 751-752.

HIGUET, E. O misticismo na experiência católica. In: BOFF, Leonardo (org.). Religiosidade popular e misticismo no Brasil. São Paulo, Paulinas, 1984.

HATTSTEIN, Markus. Religiões do mundo. Trad. Paula da Silva Bonner. Colónia: Könemann, 2000.

HOBSBAWM, Eric J. Era dos extremos: o breve século XX (1914-1991). Trad. Marcos Santarrita. São Paulo: Companhia das Letras, 1995. 
TURNER, Victor. O Processo ritual: estrutura e anti-estrutura. Trad. Nancy Campui de Castro. Petrópolis: Vozes, 1974.

SANTOS, Jael dos. Práticas e representações religiosas: o catolicismo no Sudoeste do Paraná (1930-2013). Marechal Cândido Rondon: 2013. Dissertação (mestrado em História) Universidade Estadual do Oeste do Paraná.

SELIGMANN-SILVA, Márcio. Narrar o Trauma: a questão do testemunho de catástrofes históricas. Psicologia Clínica do Rio de Janeiro, vol. 20, n. 01, p. 65-82, 2008. Disponível em: <http://www.scielo.br/pdf/pc/v20n1/05.pdf> acesso em: 20/05/2021.

STEIL, Carlos Alberto. O sertão das romarias. Petrópolis: Vozes, 1996.

\section{FONTES:}

BÍBLIA. Português. Bíblia Sagrada Ave-Maria, 157 ed. São Paulo: Editora Ave-Maria, 1959, (impressão 2003). 1632p.

Entrevista com B., A. Santa Izabel D’Oeste, 12 outubro de 2013.

Entrevista com G., R. Santa Izabel D’Oeste, 12 de outubro de 2012. Trad. Júlio César Freitas Raichert.

Entrevista com L., T. Santa Izabel D’Oeste, 12 outubro de 2013.

Entrevista com M., D., C. Santa Izabel D’Oeste, 12 de outubro de 2013.

Entrevista com N., C. Santa Izabel D’Oeste. 12 de outubro de 2012.

Entrevista com O., P. Santa Izabel D’Oeste, 12 de outubro de 2012.

Entrevista com P., E. Santa Izabel D’Oeste. 03 de abril de 2013.

Entrevista com R., M. Santa Izabel D’Oeste, 12 de outubro de 2012.

Entrevista com Z., J. Santa Izabel D’Oeste, 12 de outubro de 2012. 